\title{
Makna Nilai Nilai Sosial dalam Novel Oliver Twist Karya Charles Dickens
}

\author{
Sylvia Irene Persulessy \\ Politeknik Negeri Ambon \\ sipersulessy74@gmail.com
}

\begin{abstract}
Abstrak
Penelitian ini bertujuan untuk mengkaji secara mendalam makna nilai-nilai sosial dalam novel Oliver Twist karya Charles Dickens yang dikaji berdasarkan pendekatan struktural sastra. Penelitian ini merupakan penelitian kualitatif dengan menggunakan metode analisis isi. Pengumpulan data diperoleh dari studi pustaka berupa observasi data tentang nilai-nilai sosial dalam novel Oliver Twist. Hasil penelitian menunjukkan bahwa nilai-nilai sosial yang ditemukan dan dideskripsikan dalam novel karya Chales Dickens yaitu Nilai kasih sayang yang terdiri dari cinta dan kasih sayang, pengabdian, tolong menolong, kekeluargaan, kepedulian, dan kesetiaan. Nilai Tanggung jawab yang terdiri dari rasa menerima dan memiliki, kewajiban, dan disiplin. Nilai keserasian hidup yang terdiri dari keadilan, toleransi, kerjasama dan demokrasi. Seluruh data ditemukan dan dideskripsikan melalui struktur novel. Hasil penelitian dapat diimplikasikan bagi para pendidik untuk menggunakan novel Charles Dickens dalam proses pembelajaran agar dianalisis oleh para siswa.
\end{abstract}

Kata kunci: nilai-nilai sosial, novel Oliver Twist

\section{A. Pendahuluan}

Pengajaran apresiasi novel mempunyai peranan penting dalam membantu para generasi muda untuk lebih mengembangkan dirinya menjadi pribadi yang halus budi pekerti. Hal tersebut sejalan dengan penjelasan John Raven (1981:253) dalam salah satu artikelnya berjudul The Most Important Problem is to Come to terms with Values, yang diintisarikan oleh peneliti, antara guru, siswa, dan orang tua mempunyai kesepakatan bahwa tujuan utama dalam pendidikan yaitu mengembangkan karakter murid dan untuk mendorong dan mengembangkan hal tersebut dibutuhkan aksi 
spontan dan alami. Sejalan dengan pernyataan tersebut, menurut Sumardi (2012:10) yang diintisarikan peneliti, bahwa dengan mempelajari dan mengapresiasi sastra, maka para peserta didik akan mampu mencapai hasil yang baik dalam pengajaran berbahasa dan sastra. Selain itu pengajaran bahasa dan sastra yang baik akan berperan dalam mengembangkan Pendidikan Nasional yang bermutu dan pada akhirnya akan melahirkan generasi muda yang unggul. Dengan demikian dapat disimpulkan bahwa, melalui apresiasi sastra, para peserta didik akan mempelajari makna nilai-nilai kehidupan yang baik dan buruk kemudian mereka akan mengapresiasikan ceritacerita dalam karya sastra tersebut dan menjadikan nilai-nilai yang terkandung didalamnya sebagai contoh dan panutan dalam kehidupan bermasyarakat.

Menurut Muhardi dan Hasanuddin, (1992:15) pentingnya mengkaji makna nilai sosial dalam novel disebabkan karena sesuai fungsi sastra adalah untuk merangsang pembaca guna mengenali, menghayati, menganalisis, dan merumuskan nilai - nilai kemanusiaan. Dapat disimpulkan bahwa nilai-nilai dalam karya sastra tersebut dapat menjadi panutan, motivasi dan stabilitas kepribadian dan perilaku dari pembacanya, hal demikian tentunya juga berlaku pada nilai sosial dalam sebuah karya sastra.

Sastra dan tata nilai merupakan dua fenomena sosial yang saling melengkapi dalam hakikat mereka sebagai sesuatu yang eksistensial. Menurut Suyitno (1986:3) sastra sebagai produk kehidupan, mengandung nilai-nilai sosial, filsafat, religi, dan sebagainya baik yang bertolak dari pengungkapan kembali maupun yang mempunyai konsep baru. Sastra tidak hanya memasuki ruang serta nilai-nilai kehidupan personal, tetapi juga nilai-nilai kehidupan manusia dalam arti total. Pada hakikatnya, suatu nilai berfungsi untuk mengarahkan pertimbangan atau perilaku seseorang sehingga menjadi pedoman dalam kehidupan bermasyarakat. Kehidupan manusia berpola pada nilai sosial. Nilai sosial dapat dikatakan tolak ukur, patokan, anggapan, dan keyakinan yang dianut oleh sebagian besar anggota dalam suatu masyarakat tertentu mengenai yang benar, pantas, luhur dan baik untuk diamalkan. 
Jan Luxemburg et al (1992:24) mengatakan bahwa sastra menyajikan gambaran kehidupan itu sendiri, sebagian besar terdiri dari kenyataan sosial. Dalam pengertian ini kehidupan mencakup hubungan antar masyarakat dengan orang-orang, antar manusia, antar peristiwa yang terjadi dalam batin seseorang. Menurut Wicaksono (2014:323), nilai sosial mengacu pada hubungan individu dengan individu yang lain dalam sebuah masyarakat. Bagaimana seseorang harus bersikap, bagaimana cara mereka menyelesaikan masalah, dan menghadapi situasi tertentu juga termasuk dalam nilai sosial. Dapat disimpulkan bahwa dalam masyarakat yang sangat beraneka ragam coraknya, pengendalian diri adalah sesuatu yang sangat penting untuk menjaga keseimbangan masyarakat. Sejalan dengan tersebut nilai sosial dapat diartikan sebagai landasan bagi masyarakat untuk merumuskan apa yang benar dan penting, memiliki ciri-ciri tersendiri, dan berperan penting untuk mendorong dan mengarahkan individu agar berbuat sesuai norma yang berlaku.

Novel merupakan salah satu bentuk karya sastra yang banyak memberikan penjelasan secara jelas tentang sistem nilai. Novel merupakan salah satu bentuk refleksi pengarang terhadap nilai yang hidup dan berkembang ditengah-tengah masyarakat karena novel tidak terlepas dari sistem sosial budaya yang melingkupinya. Dengan demikian, suatu fenomena sosial dapat menjadi salah satu unsur sebuah novel. Adapun bentuk nilai-nilai sosial yang terdiri atas beberapa sub nilai menurut Zubaedi (2012:13), yaitu: 1) Nilai Kasih Sayang (Loves), nilai kasih sayang terdiri atas cinta dan kasih sayang, pengabdian, tolong menolong, kekeluargaan dan kepedulian. 2) Nilai Tanggung Jawab (Responsibility), Nilai tanggung jawab terdiri dari rasa menerima dan memiliki, kewajiban dan disiplin. 3) Nilai Keserasian Hidup (Life Harmony). Nilai keserasian hidup terdiri atas nilai keadilan, toleransi, kerja sama, dan demokrasi. Dengan melihat sub nilai yang terkandung dalam nilai-nilai sosial di atas maka dapat disimpulkan bahwa, nilai-nilai sosial tersebut sangatlah penting dalam kehidupan bermasyarakat jika diterapkan dengan baik dan benar, dan apabila dikaitkan dengan pendalaman sebuah karya sastra 
dapat menjadi suatu pembelajaran berharga tentang kehidupan, terutama kehidupan bermasyarakat.

\section{B. Metode Penelitian}

Penelitian ini adalah penelitian kualitatif dengan metode deskriptif yang menggambarkan makna nilai-nilai sosial yang terwujud dalam novel Oliver Twist karya Charles Dickens. Penelitian ini mengkaji dan mendeskripsikan makna nilainilai sosial yang terwujud dalam novel Oliver Twist karya Charles Dickens dengan cara pengabsahan data yang digunakan adalah uraian rinci. Data penelitian ini adalah data yang diambil langsung dari novel Oliver Twist karya Charles Dickens yang telah diterjemahkan ke dalam Bahasa Indonesia, yang diterbitkan pada tahun 2011 oleh penerbit Bentang Pustaka.

\section{Pembahasan}

\section{Nilai Kasih Sayang}

Kasih sayang adalah wujud dari perasaan mengasihi dan menyayangi. Perasaan kasih sayang dapat dicurahkan kepada orang yang kita kasihi dan juga mengasihi kita dengan cara mengabdikan diri, menolong dan memiliki kepedulian serta sifat kekeluargaan. Keunikan refleksi rasa kasih sayang dalam novel Oliver Twist adalah kasih sayang yang diberikan dengan tulus kepada orang asing yang belum pernah saling mengenal. Kasih sayang yang diperlihatkan adalah kasih sayang yang diawali dengan rasa iba dan kasihan.

\section{a) Cinta dan Kasih Sayang}

Perasaan cinta adalah sebuah emosi dari kasih sayang yang kuat dan ketertarikan secara pribadi. Cinta merupakan sifat baik yang mewarisi semua kebaikan, perasaan belas kasih dan sayang.

Nilai sosial cinta dan kasih sayang dalam novel Oliver Twist di gambarkan ketika Agnes sebagai seorang ibu mempertaruhkan nyawanya untuk melahirkan 
anak tercintanya yaitu Oliver Twist. Nilai ini terdapat dalam kutipan teks berikut ini:

"Wajah pucat seorang wanita muda terangkat lemah dari bantal. Dia mengucapkan kata-kata yang tak sempurna dengan suara lirih, "Biar kulihat anak itu, lalu mati.” (Dickens, 2011: 2)

Kutipan teks di atas menggambarkan suasana ketika Agnes melahirkan bayi mungilnya. Hanya kata-kata itu yang dilontarkannya hingga ia meninggal. Makna dari nilai ini cinta dan kasih sayang seorang ibu kepada anaknya dengan perjuangan dan pengorbanan yang sangat besar. Dia harus meninggalkan keluarganya untuk bisa mempertahankan anak yang dikandungnya. Walaupun pada akhirnya Agnes tidak dapat melihat Oliver bertumbuh.

\section{b) Pengabdian}

Pengabdian dalam cerita Oliver Twist diperlihatkan Oliver pada saat Rose Maylie sakit keras. Oliver diminta oleh Nyonya Maylie untuk mengantarkan surat ke kota yang jarak tempuhnya enam setengah kilometer. Hal tersebut dapat dilihat pada kutipan teks berikut ini:

Dia berlari dengan gesit menyeberangi ladang, dan menyusuri pematang-pematang yang terkadang membagi-baginya---sesekali hampir tersembunyi oleh jagung tinggi di tiap sisi, dan sesekali muncul di ladang terbuka, tempat para penyiang dan pemotong jerami sedang sibuk bekerja. Dia bahkan tak berhenti, kecuali sesekali selama beberapa detik saja untuk memulihkan napasnya, sampai dia tiba di pasar kecil amat panas serta berselimut debu di kota.

(Dickens, 2011: 337)

Dari kutipan teks di atas dapat disimpulkan bahwa, makna nilai pengabdian yang diperlihatkan oleh Oliver ketika dengan sangat bersemangat melakukan tugas yang diberikan oleh Nyonya Maylie kepadanya, bahkan jarak tempuh yang jauh sekalipun dijangkaunya dengan tanpa bersungut. Oliver tidak berjalan kaki untuk sampai ke tempat tersebut namun ia berlari, berlari untuk segera tiba di tujuan, sehingga dengan demikian dia bisa menyerahkan surat penting itu tepat pada waktunya. 


\section{c) Tolong-Menolong}

Nilai tolong-menolong dalam novel Oliver Twist tergambar pada saat Oliver ditolong oleh Tuan Brownlow setelah sidang kasus pencurian yang tidak dilakukannya. Hal tersebut dapat dilihat pada kutipan teks berikut ini:

Oliver Twist kecil berbaring telentang di trotoar, bajunya tak dikancingkan, pelipisnya bersimbah air, wajahnya putih pucat seperti mayat, dan gigil kedinginan mengguncang sekujur tubuhnya.

"Anak malang, anak malang!" kata Tuan Brownlow sambil membungkuk ke atasnya.

"Siapa saja, tolong panggilkan kereta. Cepat!"

Begitu kereta datang, Oliver dengan hati-hati dibaringkan di tempat duduk. Si pria tua pun masuk dan duduk di dekatnya. (Dickens, 2011: 105-106)

Dari kutipan teks di atas dapat disimpulkan bahwa, Tuan Brownlow sebagai korban perampokan dengan berbesar hati menolong Oliver yang sebelumnya di duga sebagai si pencopet dari penderitaan yang di alami dengan membawa Oliver ke rumahnya. Makna nilai tolong menolong ini dapat menjadi contoh bagi para pembaca, bahwa kita wajib menolong dan memiliki empati yang tinggi untuk mengasihi sesama manusia yang memerlukan pertolongan.

\section{d) Kekeluargaan}

Nilai kekeluargaan dalam novel Oliver Twist tergambar dalam kutipan teks berikut ini:

Sang wanita muda akan duduk di depan piano, memainkan lagu menyenangkan, atau menyanyikan lagu lama yang menghibur bibinya dengan suara pelan dan lembut. Tak ada lilin yang dinyalakan pada saat-saat seperti ini. Oliver akan duduk di balik salah satu jendela, mendengarkan musik merdu tersebut, merasa bahagia tak terkira. (Dickens, 2011: 329-330)

Dari kutipan teks di atas dapat disimpulkan bahwa, makna nilai kekeluargaan sangat terpancar jelas dalam suasana yang tercantum dalam kutipan teks di atas. Dalam suasana tersebut tidak Nampak perbedaan kelas sosial antara 
yang miskin dan kaya, yang ada hanya saling mencintai, saling menguatkan dan saling berbagi.

\section{e) Kepedulian}

Nilai kepedulian dalam novel Oliver Twist tergambar dalam kutipan teks berikut ini:

Oliver juga membawa ilalang segar untuk burung-burung Nona Rose, yang akan digunakan Oliver yntuk mendekorasi kandang dengan selera tinggi, berkat pengajaran cakap dari kerani desa. Ketika burung-burung sudah tampan dan rapi, biasanya ada pemberian derma kecil-kecilan untuk diberikan di desa. Jika tidak, selalu ada sesuatu untuk dikerjakan di taman atau pekerjaan mengurus tanaman, yang dilaksanakan Oliver. (Dickens, 2011: 330)

Dari kutipan teks di atas dapat disimpulkan bahwa, perilaku Oliver merupakan perwujudan makna nilai kepeduliannya terhadap lingkungan di sekitarnya. Disamping itu kepedulian Oliver terhadap pekerjaannya tersebut karena Oliver ingin menyenangkan hati Rose sebagai si pemilik lingkungan tersebut. Kepedulian Oliver mendapat pujian dari Rose, karena memang Oliver merupakan anak yang rajin dan selalu mau berusaha mengembangkan dirinya menjadi pribadi yang lebih baik.

\section{f) Kesetiaan}

Nilai kesetiaan dalam novel Oliver Twist tergambar dalam kutipan teks di berikut ini:

“Justru karena aku teman lama ayahmu, anak muda," balas Tuan Brownlow.

"Karena aku terikat padanya melalui harapan dan cita-cita di masa muda dan bahagia, dan melalui makhluk cantik yang sedarah dengannya, yang menemui Tuhan di masa muda, serta meninggalkanku sebagai seorang laki-laki yang sendirian dan kesepian. (Dickens, 2011: 515)

Dari kutipan teks di atas dapat disimpulkan bahwa, makna nilai kesetiaan yang diperlihatkan oleh Tuan Brownlow adalah persahabatan yang tulus dengan 
ayah Monks yaitu Tuan Leeford. Mereka melewati masa sulit dan senang bersama sebagai wujud rasa setia kawan dan persaudaraan. Persahabatan yang mereka jalani membuat Tuan Brownlow tetap mengenang sahabat sejatinya tersebut dan atas wujud rasa setia kepada sahabatnya tersebut, Tuan Brownlow berusaha untuk merangkul Monks agar berubah dan memiliki kehidupan yang lebih baik.

Dengan demikian dapat disimpulkan bahwa, makna nilai kesetiaan dalam novel Oliver Twist merupakan nilai positif yang harus dilakukan dan dapat menjadi contoh bagi para pembaca untuk mengaplikasikannya dalam kehidupan bermasyarakat.

\section{Nilai-Nilai Tanggung Jawab}

Tanggung jawab adalah wujud dari kesadaran manusia atas apa yang dilakukannya sebagai perwujudan kesadaran akan kewajibannya. Nilai tanggung jawab dalam novel Oliver Twist karya Charles Dickens terdiri dari nilai rasa menerima dan memiliki, nilai kewajiban, dan nilai disiplin.

\section{a) Rasa Menerima dan Memiliki}

Nilai rasa menerima dan memiliki dalam novel Oliver Twist tergambar dalam kutipan teks berikut ini:

Setiap pagi dia pergi menemui pria tua berambut putih yang tinggal di dekat gereja kecil. Pria itu mengajarinya membaca lebih baik serta menulis. Bicaranya demikian ramah dan bersedia bersusah payah membantu Oliver sehingga anak kecil itu merasa usahanya untuk menyenangkan pria itu tak pernah cukup. (Dickens, 2011: 329)

Dari kutipan teks di atas dapat disimpulkan bahwa, makna nilai rasa memiliki dan menerima tergambar pada saat Oliver mempunyai keinginan untuk belajar membaca dan menulis. Kegembiraan dan ketenangan yang diterima dan dirasakannya bersama keluarga Maylie tidak membuatnya terbuai namun Oliver berusaha menggunakan kesempatan tersebut untuk mengembangkan dirinya, dan menjadi lebih baik dengan kesempatan yang diberikan kepadanya.

\section{b) Kewajiban}


Nilai kewajiban dalam novel Oliver Twist, terdapat pada kutipan teks berikut ini:

Oliver lebih takjub lagi saat mendapati bahwa keteguhan Nyonya Maylie ini tetap bertahan dan tetap siaga serta tenang mengerjakan semua tanggung jawab yang dilimpahkan kepadanya untuk merawat dan memperhatikan Rose. Bahkan, berdasarkan penampilan luar, tetap terlihat riang. Namun, Oliver yang masih muda tidak mengetahui apa yang sanggup dilakukan oleh pikiran yang tabah dan kuat dalam kondisi penuh cobaan. (Dickens, 2011: 336)

Dari kutipan teks di atas dapat disimpulkan bahwa, makna nilai kewajiban benar-benar diterapkan oleh Nyonya Maylie dalam melayani Rose walaupun dengan hati yang sangat sedih dan tidak mampu melihat penderitaan Rose, Nyonya Maylie tetap melaksanakan kewajibannya sebagai seorang ibu kepada anaknya. Hal ini dilakukan karena Nyonya Maylie bertanggung jawab dengan keselamatan Rose Maylie anak angkatnya.

\section{c) Disiplin}

Nilai disiplin dalam novel Oliver Twist, terdapat dalam kutipan teks berikut ini:

Lalu, Oliver akan berjalan-jalan bersama Nyonya Maylie dan Rose, mendengar mereka membicarakan buku-buku, atau duduk di dekat mereka di suatu tempat teduh, serta mendengarkan Nona Rose membaca, yang sering kali dilakukan Oliver sampai hari cukup gelap untuk membaca. Lalu, dia harus mempersiapkan pelajarannya sendiri untuk esok hari. Untuk hal ini ia akan bekerja keras di sebuah ruangan kecil yang menghadap ke taman. (Dickens, 2011: 329)

Dari kutipan teks di atas dapat disimpulkan bahwa, Oliver mendisiplinkan dirinya dengan mengatur jadwal kegiatannya setiap hari. Selain bertanggung jawab untuk menemani Nyonya Maylie dan Rose berjalan-jalan, Oliver juga mempunyai waktu tersendiri untuk mengembangkan diri dengan belajar dan membaca. Agar semua hal tersebut berjalan dengan baik dan lancar, Oliver berusaha keras untuk merampungkan semua kegiatan tersebut dengan baik, 
sehingga dapat disimpulkan bahwa, apa yang dilakukan oleh Oliver adalah bentuk dari nilai disiplin.

Dengan demikian, makna nilai disiplin sangat berkaitan erat dengan nilai tanggung jawab. Makna nilai disiplin dalam karya sastra merupakan salah satu pesan bagi para pembaca, bahwa dengan mendisiplinkan diri kita terlebih dahulu maka semua hal yang kita lakukan atau rencanakan akan berjalan dengan baik dan tertanggungjawab.

\section{Nilai Keserasian Hidup}

Nilai keserasian hidup adalah perilaku manusia sebagai makhluk sosial yang berinteraksi dengan manusia lainnya dalam melakukan kegiatan bermasyarakat sehari-hari, kehidupan yang bersosialisasi tersebut dilandaskan dengan aturan-aturan yang disepakati bersama demi kenyamanan dan keserasian dalam bermasyarakat.

Nilai keserasian hidup dalam novel Oliver Twist karya Charles Dickens terdiri atas, nilai keadilan, nilai toleransi, nilai kerjasama dan nilai demokrasi.

\section{a) Keadilan}

Nilai Keadilan dalam novel Oliver Twist, terdapat dalam kutipan teks berikut ini:

Berdasarkan ketentuan yang ada dalam surat wasiat ayahnya, Oliver semestinya berhak atas seluruh harta tersebut. Namun, Tuan Brownlow rupanya tidak ingin menghilangkan kesempatan si anak sulung untuk bertobat atas kejahatan masa lalunya dan menjalani hidup yang jujur, lantas ia mengusulkan cara pembagian seperti ini, yang disetujui dengan senang hati oleh Oliver. (Dickens, 2011: 572)

Dari kutipan teks di atas terlihat jelas makna nilai keadilan yang dibuat oleh Tuan Brownlow. Warisan dari Tuan Leeford dibagi sama rata antara Oliver dan Monks, tujuan Tuan Brownlow adalah supaya Monks dapat berubah menjadi lebih baik, dan hidup berdampingan bersama Oliver saudara tirinya dalam 
kebahagiaan dan keharmonisan, hal ini adalah perwujudan dari nilai keserasian hidup.

\section{b) Toleransi}

Nilai toleransi dalam novel Oliver Twist terdapat dalam kutipan teks berikut ini:

Pada pagi hari, mereka akan pergi ke gereja kecil. Daun-daun hijau yang berayun-ayun di jendela; burung-burung yang berkicau tanpa terlihat; dan udara berbau harum menelusup masuk ke beranda rendah serta memenuhi bangunan nyaman tersebut dengan wewangiannya. Orang-orang miskin begitu bersih dan rapi. Mereka berlutut untuk berdoa dengan begitu khusyuk sehingga kegiatan berkumpul di sana tampak menyenangkan, tak tampak sebagai suatu kewajiban yang melelahkan. Meskipun nyanyiannya mungkin saja sumbang, suara tersebut lebih nyata dan terdengar lebih merdu (di telinga Oliver paling tidak) daripada nyanyian mana pun yang pernah dia dengar di gereja sebelumnya. (Dickens, 2011:330)

Dari kutipan teks di atas terlihat jelas makna nilai toleransi berupa kehidupan sosial bermasyarakat yang terjadi dalam lingkungan keluarga Maylie. Mereka berbaur menjadi satu bersama para buruh di dalam rumah ibadah, mereka bersekutu dan bernyanyi juga berdoa. Pada saat seperti ini tidak ada lagi perbedaan antara yang kaya dan miskin, kelas atas maupun kelas bawah, tujuan mereka hanyalah beribadah dan mencari sukacita.

Dengan demikian dapat disimpulkan bahwa, semakin tinggi nilai toleransi antar sesama umat manusia, maka semakin terjamin kebahagiaan, kesejahteraan dan kemakmuran suatu negeri.

\section{c) Kerjasama}

Nilai kerjasama dalam novel Oliver Twist terdapat dalam kutipan teks berikut ini:

"Aku sudah bicara kepada para laki-laki yang bertanggung jawab atas penangkapannya. Mereka memberitahuku bahwa dia tak mungkin lolos. Imbalan sebesar seratus pound diumumkan oleh pemerintah malam ini." "Akan kutambah lima puluh," kata Tuan Brownlow, "Dan akan 
kuumumkan dengan mulutku sendiri di tempat itu, jika aku bisa sampai di sana. Di mana Tuan Maylie?” (Dickens, 2011:524)

Kutipan teks di atas adalah gambaran ketika Tuan Brownlow diberitahukan bahwa, pemerintah sudah menyediakan hadiah bagi siapa saja yang berhasil menangkap Bill Sikes. Hadiah tersebut berupa uang sebesar 100 pound. Tuan Brownlow mau untuk bekerjasama dengan pemerintah dengan menambahkan uang hadiah tersebut hingga totalnya 150 pound.

Dengan demikian dapat disimpulkan bahwa, tindakan Tuan Brownlow merupakan perwujudan dari nilai kerjasama, kerjasama untuk membantu pemerintah dalam memberantas kejahatan agar kehidupan bermasyarakat semakin aman dan damai.

\section{d) Demokrasi}

Nilai demokarsi dalam novel Oliver Twist terdapat dalam kutipan teks berikut ini:

"Semua yang kuharap bisa kulakukan, dan lebih lagi. Menggabungkan informasi gadis malang itu dengan pengetahuan yang sudah kupunya sebelumnya, dan dari hasil penyelidikan teman kita yang baik di lokasi. Aku tidak akan memberinya ruang sedikit pun untuk meloloskan diri, dan dia akan memaparkan seluruh kejahatan yang kini sudah terang benderang. Tulislah surat dan tetapkan malam lusa, pukul tujuh, untuk rapat." (Dickens, 2011: 525)

Kutipan teks di atas menggambarkan tentang keputusan Tuan Brownlow mengumpulkan semua saksi untuk bertemu langsung dengan Monks, Oliver dan Rose. Tujuannya adalah untuk menyingkapkan semua rahasia yang selama ini disembunyikan, sekaligus mengungkap semua kejahatan yang direncanakan oleh Monks.

Dengan demikian dari kutipan teks ini dapat disimpulkan bahwa, ada upaya dari Tuan Brownlow untuk mewujudkan suatu nilai demokrasi guna menegakkan kebenaran dan keadilan dalam sebuah permasalahan yang menjadi sumber konflik. 


\section{Kesimpulan}

Nilai-nilai sosial ditinjau dari makna nilai kasih sayang, nilai tanggung jawab dan nilai keserasian hidup dalam novel Oliver Twist karya Charles Dickens terlihat jelas dalam isi cerita novel ini. Uraian nilai-nilai sosial dalam cerita menggambarkan secara jelas bagaimana cara hidup manusia yang memiliki keburukan yang tampak dalam perilaku negatif dimenangkan oleh nilai-nilai kehidupan yang positif yang diperlihatkan oleh beberapa tokoh dalam cerita ini. Nilai-nilai tersebut adalah nilai cinta dan kasih sayang, nilai pengabdian, nilai tolong menolong, nilai kekeluargaan, nilai kepedulian, nilai kesetiaan, nilai rasa menerima dan memiliki, nilai kewajiban, nilai disiplin, nilai keadilan, nilai toleransi, nilai kerjasama dan nilai demokrasi. Keseluruhan nilai-nilai tersebut

dihubungkan dengan kutipan teks yang tergambar dalam isi cerita, merupakan makna nilai-nilai sosial dari sebuah karya sastra dari novel Oliver Twist karya Charles Dickens.

\section{Daftar Pustaka}

Dickens Charles, 2011. Oliver Twist. Yogyakarta: Bentang Pustaka.

Jan van Luxemburg et al., 1992. Pengantar Ilmu Sastra. Jakarta: Gramedia.

Muhardi dan W. S. Hassanudin, 1992. Prosedur Analisis Fiksi. Padang: IKIP

Raven John, 1981. "The Most Important Problems in Education is to Come to Terms with Values", Oxford Review of Education, Vol, 7, No. 3.

Sastra Suyitno, 1986. Tata Nilai dan Eksegesis. Jakarta: PT Hanin Data.

Sumardi, 2012. Panduan Apresiasi Cerpen untuk Siswa dan Mahasiswa, Jakarta: UHAMKA Press.

Sutarjo Adisusilo, 2012. Pembelajaran Nilai karakter. Jakarta: Rajawali Press. Wicaksono Andri, 2014. Pengkajian Prosa Fiksi. Yogyakarta: Garudawhaca. Zubaedi, 2012. Pendidikan Berbasis Masyrakat. Yogyakarta: Pustaka Pelajar. 